\title{
PENGARUH GAYA HIDUP TERHADAP PENGGUNAAN CREAM PEMUTIH WAJAH PADA MAHASISWA JURUSAN ANALIS KESEHATAN POLTEKKES KEMENKES RI MEDAN
}

\author{
Dewi Setiyawati \\ Jurusan Analis Kesehatan Poltekkes Kemenkes Medan
}

\begin{abstract}
The widespread cosmetic use influenced by the life style of community recently has caused the increasing incident of skin disease or disorder due to the use of cosmetic. The incident of skin disorder, among other things, is caused by the wrong or excessive use of cosmetic, the poor cosmetic process, and the inappropriate use of active ingredients in cosmetics. This condition is the background of this study. The purpose of this explanatory survey study with the description of causal relationship between the variables through hypothesis testing was to analyze the influence of life style on the use of whitening facial cream by the students of Health Analyst Department of Health Polytechnic, Ministry of Health, Republic of Indonesia, Medan. The population of this study was all of the 239 students in the Health Analyst Department of Health Polytechnic, Ministry of Health, Republic of Indonesia, Medan. The result of this study with 4 (four) variables on 76 respondents using the whitening facial cream showed that 55 respondents (72.4\%) used the whitening facial cream because of the factors of knowledge, 56 respondents (73.7\%) because of students' attitude, 41 respondents (53.9\%) because of peer influence, and 46 respondents (60.5\%) because of media influence. The result of statistical test using Chi-square test at $\alpha=95 \%(p<0.05)$ showed that there was the influence of life style on the use of whitening facial cream in the students in the Health Analyst Department of Health Polytechnic, Ministry of Health, Republic of Indonesia, Medan in which the factors of knowledge ( $p=$ $0.027<0.05)$, peer influence $(p=0.012<0.05)$, and media influence $(p=0.004<0.05)$. However, the result of the second multivariate test showed that media influence had the most dominant and significant influence $(p=0.004<0.05)$ with $B=2.069$ and the factor of attitude did not have any influence at all $(p=$ 0.275 > 0.05). Community members are suggested to be alert in choosing and using the cosmetics with whitening cream. The desire to looking beautiful should not be materialized by using any product that can bring bad impact to your face. Good eating pattern and healthy life can help make your skin and body smooth. If you want to use whitening facial cream, you may use the one which has been analyzed and tested by BPOM (Drugs and Food Control Agency). The prohibited certain brands can be found out in the media or releases issued by BPOM (Drugs and Food Control Agency).
\end{abstract}

Keyword : Life Style, Whitening Facial Cream

\section{PENDAHULUAN}

Munculnya penampilan perempuan dalam berbagai media baik media cetak maupun media elektronik tidak seluruhnya menggambarkan ruang lebih lebar untuk melihat secara kritis kedudukan perempuan dalam masyarakat, tetapi masih ideologis tentang perubahan gaya hidup, gaya hidup dapat memberikan pengaruh positif atau bahkan bisa menjerumuskan ke dalam hal-hal yang negatif bagi yang menjalankannya. Kehidupan yang sangat ngetrend terdapat dikehidupan modern pada saat ini pada kota-kota besar seperti jalan-jalan ke mall, pergi clubing, hang out bersama teman-teman di cafe, menjadi ciri khas kehidupan yang biasa terlihat.

Gaya hidup adalah hasil dari pergaulan diri kita dalam pencarian identitas dan sensibilitas kita dengan lingkungan dimana kita hidup bagaimana seseorang itu bisa terlihat cantik, menarik, anggun, dan glamour untuk dapat hidup mewah seperti layaknya selebritis dunia yang menghabiskan uang dan waktunya. Gaya hidup merupakan pola hidup dimana seseorang membagi, menghabiskan dan mengelola waktu dan uangnya, yang diukur melalui pola asuh dan pola hidup (John C. Mowen dan Michel Minor, 1998), (James F. Engel,Roger D Black Well, dan Paul W. Miniard, 1994), (J. Paul Peter, Jerry C. Olsen, 1999).

Chaney (2003) juga mengatakan pada akhir modrenitas semua yang kita miliki akan menjadi budaya tontonan semua orang ingin menjadi penonton dan sekaligus di tonton ingin melihat tapi sekaligus di lihat, kamu bergaya maka kamu ada kalau kamu tidak bergaya siap siaplah untuk di anggap "tidak ada” di abaikan, di remehkan, atau mungkin di lecehkan itulah sebabnya kita perlu bersolek atau berias diri.

Gaya hidup menunjukkan pola kehidupan orang yang bersangkutan yang tercermin dalam kegiatan seharihari, minat, perilaku, dan pendapatannya terhadap sesuatu 
hal yang sudah melekat pada diri personal seseorang konsep ini bila di gunakan oleh pemasar secara cermat dapat membantu untuk memahami nilai-nilai konsumen yang terus berubah dan bagaimana nilai-nilai tersebut dapat mempengaruhi perilaku konsumen (Bilson Simamora, 2004).

Meluasnya pemakaian kosmetik yang dipengaruhi oleh gaya hidup masyarakat pada akhir-akhir ini telah menyebabkan meningkatnya insidensi penyakit atau kelainan kulit akibat pemakaian kosmetik. Pengaruh tersebut berupa reaksi yang dikehendaki atau efek samping yang tidak dikehendaki. Kelainan kulit yang terjadi antara lain disebabkan cara pemakaian kosmetik yang salah atau berlebihan, pengolahan kosmetik yang kurang baik, penggunaan bahan-bahan aktif dalam kosmetik yang tidak tepat (Purwanto, 2009).

Balai Besar Pengawas Obat dan Makanan (BB POM), tanggal 11 Juni 2009, mengeluarkan Publik Warning No. KH.00.01.43.2503 mengenai penarikan peredaran 70 item kosmetik yang mengandung bahan berbahaya atau bahan dilarang Merkuri, Hidrokinon, Asam Retinoat, Zat Warna Merah K.3 (CI 15585), Merah K.10 (Rhodamin B) dan Jingga K.1 (CI 12075). 70 item tersebut terdiri dari: 18 produk Kosmetik Rias Wajah dan Rias Mata, 7 produk Kosmetik Pewarna Rambut, 1 produk Kosmetik Sediaan Mandi, yang terbanyak adalah 44 produk Kosmetik Perawatan Kulit.

Larangan tersebut ditindak lanjuti dengan penarikannya oleh Balai Besar Pengawas Obat dan Makanan (BBPOM) di berbagai daerah di seluruh Indonesia, seperti yang dilakukan BBPOM di Medan dengan menarik 57 merk kosmetik yang dilarang termasuk kosmetik yang tidak terdaftar, diantaranya kosmetik pemutih (Sumutcyber, 2008).

Bagi banyak wanita mode atau trend baru yang muncul sangat mempengaruhi penampilannya dan sering kali yang menjadi perhatian adalah kulit, terutama kulit wajah. Hal tersebut membuat orang menggunakan berbagai kosmetik pemutih sebagai jalan pintas yang menjanjikan. Kulit sehat akan memberikan kesan segar sehingga wajah terlihat bersinar dan bersih. Berbagai kosmetik pemutih wajah dengan aneka merek, jenis, dan iklan menggiurkan pun bermunculan seperti jamur di musim hujan. Hal ini sesuai dengan penelitian lain yang dilakukan bahwa 70\%-80\% perempuan di Asia (yaitu : Cina, Thailand, Taiwan, dan Indonesia) ingin mempunyai kulit yang lebih putih. Sedangkan di Indonesia dari 85\% penduduk wanita yang berkulit gelap sebanyak 55\% diantaranya ingin agar kulitnya menjadi lebih putih (Nandityasari, 2009).

Gempuran promosi akan produk pemutih kulit tampaknya telah sukses membentuk opini kaum wanita bahwa kulit putih lebih menarik dan lebih cantik dibanding sawo matang atau hitam. Para pelaku bisnis akan mempromosikan dan memasarkan produknya melalui iklan yang menggambarkan produk mereka guna mencapai kepentingan mereka yaitu meraih keuntungan yang maksimal (Purwanto, 2009).

Penelitian Kusantati, dkk (2008), yang menyatakan bahwa perkembangan ilmu kosmetik serta industrinya baru dimulai secara besar-besaran pada abad ke 20 dan kosmetik menjadi salah satu bagian dari dunia usaha. Pada akhirnya, segala jenis produk kosmetik baik dalam bentuk lotion, pembersih wajah, sabun, cream malam, sampai bedak, yang menjanjikan warna kulit lebih putih sangat laku di pasaran (Sehatnews.com, 2011).

Pada prinsipnya, dalam jangka waktu lama cream pemutih memang dapat menghilangkan atau mengurangi hiperpigmentasi pada kulit. Berkurangnya hiperpigmentasi, kulit akan terlihat lebih putih. Zat pengubah pigmen seperti ini tentu dapat menimbulkan dampak di kemudian hari, sebab ada proses fisiologis normal yaitu pembentukan pigmen yang diganggu. Penggunaan terus-menerus justru akan menimbulkan pigmentasi dengan efek permanen. Akhirnya, kulit bisa menjadi lebih hitam daripada sebelumnya.

Rata-rata semua pemutih instan akan menimbulkan efek rebound saat pemakaian dihentikan, yaitu memberikan respon yang berlawanan. Pada awalnya memang terlihat bagus (dalam beberapa hari saja, kulit menjadi lebih mulus, kenyal, dan lebih putih), akan tetapi saat pemakaian dihentikan kulit akan menjadi gelap dan dapat timbul flek-flek atau kulit menjadi merah seperti udang rebus, kasar, bahkan mengelupas seperti kulit ular.

Efek samping kosmetik pada kulit sudah sejak lama ditemukan. Beberapa peneliti telah melakukan berbagai penelitian mengenai hal tersebut. Menurut Tzank (1955) sebanyak 7\% dari semua kasus kerusakan kulit di sebuah klinik di Paris adalah akibat kosmetik. Sidi (1956) memperkirakan bahwa untuk seluruh Perancis angka ini mencapai 20\%. Schulz (1954) menemukan bahwa di Hamburg, Jerman sekitar $10 \%$ dari semua kontak dermatitis disebabkan oleh preparat kosmetik. Di Indonesia, penelitian yang dilakukan Dr. Retno Tranggono (1978) terhadap 244 pasien RSCM yang menderita nodanoda hitam 18,3\% disebabkan oleh kosmetik (Tranggono dkk, 2007).

Berdasarkan catatan Yayasan Pemberdayaan Konsumen Kesehatan Indonesia (YPKKI, 2009), berkalikali menerima pengaduan konsumen akibat penggunaan produk pemutih kulit. Ada salah satu konsumen mengalami belang-belang pada wajah, seperti panu dengan warna kemerahan dan iritasi, akibat pemakaian cream pemutih. Pemakaian merkuri dalam krim pemutih wajah bisa menimbulkan perubahan warna kulit, alergi, bintik hitam hingga iritasi. Manifestasi gejala keracunan merkuri akibat pemakaian krim kulit muncul sebagai gangguan sistem saraf, seperti tremor, insomnia, kepikunan, gangguan penglihatan, gerakan tangan abnormal (ataxia), gangguan emosi, gagal ginjal, batu ginjal.

Merkuri (Hg)/Air Raksa termasuk logam berat berbahaya, yang dalam konsentrasi kecilpun dapat bersifat racun. Pemakaian merkuri dalam kosmetik pemutih dapat menimbulkan berbagai hal, mulai dari perubahan warna kulit yang pada akhirnya dapat menyebabkan bintik-bintik hitam pada kulit, alergi, iritasi kulit serta pemakaian dengan dosis tinggi dapat menyebabkan kerusakan permanen otak, ginjal dan gangguan perkembangan janin bahkan paparan jangka pendek dalam dosis tinggi juga dapat menyebabkan muntah-muntah, diare dan kerusakan 
paru-paru serta merupakan zat karsinogenik (penyebab kanker) pada manusia (Irfan, 2007).

Di satu sisi, konsumen kosmetik selalu bertambah, dan pasti akan diikuti dengan peningkatan kejadian efek samping kosmetik. Di sisi lain, informasi mengenai produk kosmetik tidak bertambah luas dari masa ke masa. Atau sekalipun ada, keterangan tersebut tidak dapat memenuhi kebutuhan yang ada (Purnamawati, 2009).

Kecenderungan menunjukkan bahwa penggunaan kosmetik pemutih pada masyarakat membuat produsen kosmetik bersaing dalam memproduksi dan mempromosikan produk kosmetik pemutih. Mereka cenderung mencoba-coba dan berharap kulitnya menjadi putih dan cantik.

Penelitian yang dilakukan di Akademi Kebidanan Hafsah Medan oleh Deviana (2009) menunjukkana hasil : dari 74 mahasiswa diperoleh bahwa 36,49 \% menyatakan mereka pernah menggunakan kosmetik pemutih wajah walaupun kosmetik yang digunakan tidak memiliki izin dari BPOM, 35,14\% menyatakan pernah menggunakan salah satu kosmetik yang mengandung merkuri (Hg), dan $32,43 \%$ menyatakan pernah menggunakan kosmetik yang dilarang peredarannya oleh BPOM, serta 55,41\% responden membeli produk di tempat penjualan kosmetik yang tidak resmi.

Penggunaan kosmetik terutama cream pemutih wajah, hal ini bisa disebabkan oleh banyak faktor, seperti terbatasnya informasi/pengetahuan baik dari media elektronik dan cetak, mengikuti trend/mode di kalangan mahasiswa, minimnya informasi dari produsen kosmetik pemutih, minimnya sosialisasi dari pemerintah mengenai kosmetik pemutih yang beredar di Indonesia.

Mahasiswa menggunakan kosmetik dikarenakan adanya dukungan dari kelompoknya (teman, media) bahwa menggunakan cream pemutih wajah akan menjadikan mereka lebih cantik. Cream pemutih wajah yang banyak digunakan oleh mahasiswa adalah cream pemutih wajah yang didapat dari warung/kedai yang menyediakan cream pemutih wajah tersebut, maupun mereka akan membeli cream pemutih wajah secara bersama-sama, dan umumnya mereka dapatkan di salah satu pasar yang ada di Kota Medan (Fina, 2006).

Penggunaan cream pemutih wajah secara terus menerus di kalangan mahasiswa akan memberikan dampak, baik secara langsung maupun tidak langsung. Sehingga kebiasaan menggunakan cream pemutih wajah akan terus langgeng dan bertahan lama. Padahal belum tentu cream pemutih wajah yang mereka gunakan adalah cream pemutih wajah yang mendapat izin resmi dari pemerintah dan tidak berbahaya.

Umumnya masalah kesehatan, seperti halnya efek samping penggunaan kosmetik pemutih pada mahasiswa, dipengaruhi oleh dua faktor pokok, yaitu faktor perilaku dan faktor-faktor di luar perilaku. Faktor perilaku ini mempunyai pengaruh yang besar terhadap status kesehatan individu maupun masyarakat. Hal ini sesuai dengan semua aktivitas yang kita lakukan merupakan perilaku, dimana perilaku adalah hasil dari segala macam pengalaman serta interaksi manusia dengan lingkungannya yang terwujud dalam bentuk pengetahuan, sikap dan tindakan. Selain itu perilaku adalah semua kegiatan atau aktivitas manusia, baik yang dapat diamati langsung maupun yang tidak dapat diamati oleh pihak luar (Sarwono, 2004; Notoatmojo, 2007).

Berdasarkan pengamatan yang dilakukan di Jurusan Analis Kesehatan Poltekkes Kemenkes RI Medan, sekarang ini mahasiswa tingkat I, II maupun III cenderung memiliki masalah atau keluhan tentang kulit mereka, terutama kulit wajah seperti timbulnya adanya noda bekas jerawat, jerawat, maupun warna kulit wajah yang kurang putih dan kurang bersih, dengan adanya berbagai macam merek kosmetik pemutih yang beredar di pasaran telah menarik minat mahsiswa untuk menggunakannya, mereka cenderung mencoba-coba dan berharap kulitnya menjadi putih dan cantik. Mahasiswa menggunakan kosmetik pemutih sebagai solusi masalah kulitnya tanpa memperhatikan dan mempertimbangkan dampak dari kosmetik pemutih tersebut.

Berdasarkan survei pendahuluan peneliti di kampus Jurusan Analis Kesehatan Poltekkes Kemenkes RI Medan, banyak mahasiswa yang menggunakan cream pemutih wajah. Mahasiswa menggunakan cream pemutih wajah dengan alasan kecantikan. Dari enam (6) lokal kelas yang ada didapat 25 mahasiswa putri menggunakan cream pemutih wajah. dengan rata-rata lama pemakaian cream pemutih wajah lebih dari enam (6) bulan. Sebagian dari mahasiswa yang menggunakan cream pemutih wajah tersebut ada yang menunjukkan gejala efek samping berupa merah di wajah, rasa gatal, muncul flek hitam.

Penggunaan kosmetik pemutih pada mahasiswa Jurusan Analis Kesehatan Poltekkes Depkes RI Medan diperkirakan merupakan bentuk perilaku pemeliharaan kesehatan, karena tujuan pengunaan kosmetik tersebut selain untuk menutupi wajah dari paparan sinar matahari langsung juga bagian dari merawat kecantikan. Selain itu mahasiswa menggunakan cream pemutih wajah sangat berkaitan dengan bagaimana mereka membentuk image di mata orang lain, berkaitan dengan status sosial yang disandangnya. Untuk merefleksikan image inilah, dibutuhkan simbol-simbol status tertentu, yang sangat berperan dalam mempengaruhi perilaku mahasiswa

Cream pemutih wajah yang digunakan oleh mahasiswa kebanyakan didapat dari informasi teman dan juga pengaruh media. Dari informasi yang didapat dari teman bahwa ada cream pemutih yang bisa membuat wajah kelihatan cantik.

Berdasarkan permasalahan yang diuraikan di atas, maka peneliti ingin mengetahui pengaruh gaya hidup terhadap penggunaan cream pemutih di Jurusan Analis Kesehatan Poltekkes Kemenkes RI Medan.

\section{TUJUAN PENELITIAN}

Untuk menganalisis pengaruh gaya hidup terhadap penggunaan cream pemutih wajah oleh mahasiswa di Jurusan Analis Kesehatan Poltekes Kemenkes RI Medan 


\section{MANFAAT PENELITIAN}

1. Sebagai masukan kepada Dinas Kesehatan dan Balai POM untuk melakukan pengecekan dan pengawasan penggunaan produk kosmetik yang berbahaya.

2. Sebagai masukan bagi Poltekes Kemenkes RI Medan khususnya Jurusan Analis Kesehatan dan masyarakat pada umumnya tentang pentingnya pencegahan dari penggunaan kosmetik pemutih.

3. Sebagai pengembangan keilmuan dalam bidang kesehatan masyarakat yang bekaitan dengan penggunaan cream pemutih wajah.

\section{METODE PENELITIAN}

\section{A. Jenis Penelitian}

Penelitian ini merupakan penelitian survey dengan pendekatan explanatory reseach yaitu penjelasan yang ditujukan untuk menganalisis pengaruh gaya hidup mahasiswi terhadap penggunaan cream pemutih wajah di Jurusan Analis Kesehatan Poltekkes Kemenkes RI Medan. Survey explanatory adalah penjelasan hubungan kausal antara variabel-variabel melalui pengujian hipotesis.

\section{B. Lokasi dan Waktu Penelitian Lokasi Penelitian}

Penelitian dilakukan di Jurusan Analis Kesehatan Poltekkes Kemenkes RI Medan dengan alasan bahwa banyak mahasiswi yang menggunakan cream pemutih wajah agar mereka terlihat lebih cantik dan putih.

\section{Waktu Penelitian}

Penelitian dilakukan dari peoses pengajuan judul, pencarian literatur, konsultasi dengan pembimbing, proposal, penelitian, pengolahan data, penyajian data, pembahasan kesimpulan dan saran. Keseluruhan proses penelitian tersebut dilakukan pada bulan Oktober 2011 Januari 2012.

\section{Populasi dan Sampel}

\section{A. Populasi}

Populasi dalam penelitian ini adalah seluruh mahasiswi yang ada di Jurusan Analis Kesehatan Poltekkes Kemenkes RI Medan, dimana jumlah semua mahasiswi jurusan analis kesehatan berjumlah 239 orang.

\section{B. Sampel}

Penentuan sampel pada penelitian ini dilakukan dengan menggunakan metode random sampling , kemudian besar sampel ditentukan dengan menggunakan rumus Slovin dalam Soleh (2005)

$$
n=\frac{N}{1+N(d)^{2}}
$$

Keterangan:

$\mathrm{n} \quad$ : Jumlah sampel

$\mathrm{N}$ : Jumlah populasi yang diketahui ( $\mathrm{N}=239$ orang)

d : Presisi atau tingkat kepercayaan/ketepatan yang diinginkan ( $\mathrm{d}=10 \%$ atau 0,1$)$.
Perhitungan besarnya sampel adalah :

$$
\begin{aligned}
& n=\frac{239}{1+239(0,1)^{2}} \\
& n=\frac{239}{1+239(0,01)} \\
& n=75,5 \quad \text { maka jumlah sampel dibulatkan }
\end{aligned}
$$
menjadi 76 orang.

Berdasarkan hasil perhitungan diatas, maka jumlah sampel dalam penelitian ini adalah sebanyak 76 orang. Pengambilan sampel ditentukan dengan menggunakan proportional sampling dengan menghitung nilai sample fraction. Sample fraction adalah proporsi sampel dengan perbandingan sampel terpilih dengan jumlah populasi (Sedarmayati dan Hidayat, 2002). Rumus sample fraction dalam penelitian ini adalah:

$$
\text { Sampel }=\frac{\text { Populasi tingkat } \text { kelas }}{\text { Total } \text { Populasi }} \times \text { Total sampel }
$$

Maka sampel pada masing-masing Tingkat Kelas di Jurusan Analis Poltekkes RI Medan dapat dilihat pada tabel 3.1 berikut :

Tabel 3.1 Perhitungan Jumlah Sampel Penelitian Mahasiswa Jurusan Analis Kesehatan Poltekkes Kemenkes RI Medan

\begin{tabular}{ccccc}
\hline No & $\begin{array}{c}\text { Tingkat } \\
\text { Kelas }\end{array}$ & Populasi & Perhitungan & $\begin{array}{c}\text { Jumlah } \\
\text { Sampel }\end{array}$ \\
\hline 1. & Tingkat I & 90 & $90 / 239 \times 76$ & 29 \\
2. & Tingkat II & 71 & $71 / 239 \times 76$ & 22 \\
3. & Tingkat III & 78 & $78 / 239 \times 76$ & 25 \\
\hline & Jumlah & $\mathbf{2 3 9}$ & & $\mathbf{7 6}$ \\
\hline
\end{tabular}

Pengambilan sampel terpilih dari setiap tingkat kelas dilakukan dengan metode simple random sampling yaitu mengambil sampel secara acak dengan cara undian sampai memenuhi jumlah sampel yang dibutuhkan.

\section{HASIL DAN PEMBAHASAN}

\section{A. Pengaruh Pengetahuan terhadap Penggunaan Cream Pemutih Wajah}

Dari hasil jawaban responden pada kuesioner tentang pengetahuan yang dimiliki ternyata dipengaruhi oleh pengetahuan sebagai mahasiswa analis kesehatan berkaitan dengan faktor pendidikan. Sebanyak 76 responden diambil samplenya ternyata yang menyatakan bahwa mereka mempunyai pengetahuan yang baik tentang cream pemutih wajah ada sebanyak 55 orang yang menjawab mengetahui tentang bahaya cream pemutih, namun sebanyak 34 orang atau $61,8 \%$ tetap menggunakan cream pemutih, dan sebanyak 21 orang atau 38, 2\% tidak menggunakan cream pemutih dan dari 21 orang yang menjawab kurang memiliki pengetahuan tentang cream pemutih ternyata ada sebanyak 19 orang atau $90,5 \%$ tmenggunakan cream pemutih dan sebanyak 2 orang atau 9,5\% tidak menggunakannya.. 
Hal yang membuat peneliti tertarik dalam penelitian ini adalah, bahwa pengetahuan yang diperoleh dari pendidikan ternyata tidak membuat para mahasiswa mengurungkan niatnya menggunakan cream pemutih wajah, pengaruh gaya hidup dan ingin tampil cantik membuat mahasiswa tidak menghiraukan adanya bahaya yang lambat laun akan dideritanya, ini sesuai dengan pernyataan dari Channey memberikan suatu definisi sebagai berikut : Gaya hidup adalah pola-pola tindakan yang membedakan antara satu orang dengan orang lain. Gaya hidup merupakan bagian dari kehidupan sosial sehari-hari dunia modern. Gaya hidup adalah seperangkat praktik dan sikap yang masuk akal dalam konteks waktu.

Mahasiswa menggunakan cream pemutih berdasarkan pola hidup ingin bergaya atau kebiasaan yang pengetahuannya diperoleh dari sosialisasi kehidupan sehari-hari namun hal ini mengakibatkan pengaruh pada diri seseorang untuk menggunakan cream pemutih tanpa mempertimbangkan pengetahuannya tentang cream pemutih dari dunia pendidikan yang sedang dijalaninyaninya, tingkat pengetahuan yang diamati pada penelitian ini yakni sebatas tahu (know) yang diukur dari kemampuan responden mengingat suatu materi yang telah dipelajari sebelumnya (Notoatmodjo, 2005) dan Pengetahuan dapat didefenisikan sebagai suatu ingatan terhadap materi yang dipelajari, yaitu meliputi ingatan terhadap jumlah materi yang banyak dari fakta-fakta yang khusus, hingga teori-teori yang lengkap (Zaini dkk, 2002). Artinya adalah materi-materi pengetahuan tentang kosmetik dan bahaya cream pemutih yang terkandung didalamnya dapat membahayakan diri dari si mahasiswa itu sendiri yang menggunakannya, walau ternyata dapat dipengaruhi hingga si mahasiswa rela berkorban agar dapat bergaya didalam kehidupan dan sosialnya sehari-hari.

Pengetahuan tentang bahaya penggunaan cream pemutih wajah ternyata tidak menghalangi mahasiswa untuk memakainya, berpenampilan cantik dan menarik masih menjadi alasan mahasiswa. Hal ini dapat dilihat dari hasil analisis multivariat menunjukkan $(P$ value $=$ $0,027<0,05)$. Dengan nilai $B=1,934$ bahwa ada pengaruh pengetahuan terhadap penggunaan cream pemutih wajah Mahasiswa Jurusan Analis Kesehatan Poltekkes Kemenkes RI Medan.

Pengetahuan pada hakikatnya adalah segenap apa yang diketahui manusia mengenai suatu objek yang langsung maupun tidak langsung ikut mempengaruhi kehidupan manusia. Pengetahuan pada umumnya untuk menjawab dan memberikan solusi permasalahan hidup individu maupun kelompok. Seseorang atau kelompok, bahkan bangsa dengan menguasai pengetahuan akan memberikan kemampuan baginya yang selanjutnya akan membantu memecahkan masalah serta mengembangkan dan mengarahkannya kegaris yang benar. Maka pengetahuan menuntun kita untuk melakukan atau bertindak yang benar namun ada kalanya pengetahuan dapat dipengaruhi oleh kepentingan-kepentingan kelompok atau keinginan individu sesaat yang dapat berakibat baik maupun buruk.

Dapat dijelaskan juga pengetahuan dan persepsi yang digabungkan dengan pengalaman langsung dengan suatu objek dan berhubungan dengan informasi dari berbagai sumber. Pengetahuan dan persepsi mengambil bagian dari keyakinan (Schiffman dan Kanuk, 2004). Pernyataan ini atau teori-teori ini sebenarnya dapat menuntun mahasiswa untuk dapat bersikap benar dan mengaplikasikan ilmu pengetahuan yang diperolehnya atau pendidikan yang ditekoninya sesuai dengan bidang atau disiplin ilmunya tentang kesehatan, namun pengetahuan gaya hidup yang diperolehnya mengabaikan semuanya, ingin tampil cantik dan bergaya agar dapat menyesuaikan diri terhadap dunia modern, gaya hidup merupakan bagian dari pada pergaulan dan dunia modern Menurut David Channey (2000) gaya hidup telah menjadi ciri sebuah dunia modern. Artinya, siapapun yang hidup dalam masyarakat modern akan menggunakan gagasan tentang gaya hidup untuk menggambarkan tindakannya sendiri maupun orang lain. Tentang konsep gaya hidupnya.

Konsep gaya hidup yang kita lakoni dapat berakibat positif namun tidak jarang pula yang membuat kita terjerumus terhadap pola-pola gaya hidup yang menyesatkan, dampak dari pengguanaan cream pemutih yang berbahaya dan telah dilarang oleh pemerintah dalam hal ini BPOM tetap saja dilanggar, hasil penelitian ini jelas terlihat bahwa adanya mahasiswa menggunakan cream pemutih wajah merupakan pengaruh pengetahuan gaya hidup terhadap penggunaan cream pemutih wajah oleh mahasiswa jurusan analis kesehatan poltekkes Kemenkes RI Medan, yang artinya adalah mahasiswa poltekkes jurusan analis kesehatan kemenkes RI Medan tetap mengikuti perkembangan zaman dan pola-pola hidup modern, menggunakan cream pemutih wajah merupakan gaya hidup atau pola hidup modern para remaja dan mahasiswa.

Memiliki pengetahuan tentang bahan yang terkandung pada kosmetik yang dipergunakannya yaitu cream pemutih wajah ternyata tidak menuntun mahasiswa bertindak yang benar, dari hasil sebanyak 61,8\% artinya adalah lebih dari setengah mahasiswa yang mengabaikan bahaya cream pemutih wajah walau pun mereka mempnunyai pengetahuan yang cukup tentang itu. Kontaminasi kehidupan modern yang negatif atau gaya hidup yang salah ternyata telah dan tanpa disadarinya sekarang telah dimasukinya, cepat atau lambat bahaya penggunaan cream pemutih yang berkepanjangan atau dalam jangka waktu lama dengan hanya alasan ingin tampil cantik putih menarik dan tidak beda dengan komunitasnya, akan dirasakan lebih dari setengah mahasiswa poltekkes jurusan analis kesehatan Kemenkes RI Medan. Pergunkanlah pengetahuan untuk memilih hidup yang benar.

\section{B. Pengaruh Teman terhadap Penggunaan Cream Pemutih Wajah}

Hidup bersosialisasi yang berhubungan dengan masyarakat merupakan kehidupan yang wajar, walau kadang dapat berdampak baik maupun tidak 
baik, wajar bila seseorang tidak ingin berpenampilan beda dengan teman-temannya atau komunitas sesama mahasiswa, berbagi pengalaman merupakan bahagian kehidupan sehari-hari yang dapat menjadikan mereka terlihat sama akibat terpengaruh oleh penampilan atau menjadi gaya hidup mereka.

Berdasarkan penelitian terhadap 76 orang responden diketahui bahwa sebanyak 42 orang (55,3\%) mahasiswa menyatakan menggunakan cream pemutih wajah karena pengalaman teman yang sudah menggunakan sebelumnya, hasil ini sesuai dengan pendapat yaitu teman adalah salah satu faktor yang memiliki pengaruh signifikan terhadap gaya hidup remaja perempuan (Hotland, 2002 ) Dominasi pengaruh teman dapat disesuaikan dalam penelitian ini dari teori yang menyatakan Kuatnya pengaruh kelompok sebaya terjadi karena remaja lebih banyak berada di luar rumah bersama dengan teman sebaya sebagai kelompok. Kelompok teman sebaya memiliki aturan tertentu yang harus dipatuhi oleh remaja sebagai anggota kelompoknya. Penyesuaian remaja terhadap norma dengan berperilaku sama dengan kelompok teman (Monks dkk, 2004,).

Hal ini terlihat dari hasil analisis multivariat menunjukkan $(P$ value $=0,012<0,05)$. Dengan nilai $\mathrm{B}$ $=1,620$ bahwa ada pengaruh teman terhadap penggunaan cream pemutih wajah pada Mahasiswa Jurusan Analis Kesehatan Poltekkes Kemenkes RI Medan.

Penampilan cantik sering menjadi inspirasi buat orang-orang disekitarnya, baik karena gaya busana mereka, gaya rambut mereka, kehalusan kulit wajah mereka ataupun perilaku mereka yang baik dan memang pantas diteladani . Ada dua hal yang menyebabkan seseorang menjadi konform yaitu pengaruh norma dan pengaruh informasi. Menurut (Sarwono, 2001). Pengaruh norma disebabkan oleh keinginan remaja untuk memenuhi harapan teman sebayanya sehingga dapat diterima oleh kelompoknya. Remaja akan mengikuti keinginan atau harapan teman sebayanya semata-mata hanya untuk mendapatkan penghargaan atau untuk menghindari hukuman, seperti takut dikatakan tidak gaul atau dijauhkan oleh teman-temannya. Sedangkan pengaruh informasi disebabkan karena adanya bukti-bukti dan informasi-informasi mengenai realitas yang diberikan oleh teman sebaya. Ketika remaja mampu berperilaku sama dalam aktivitas, minat dan memanfaatkan waktunya maka remaja akan menerima umpan balik mengenai kemampuannya. Hal ini terjadi karena individu percaya dengan apa yang dilakukan teman sebayanya tersebut sesuai dengan nilai-nilai yang ada dalam dirinya.

\section{Pengaruh Media terhadap Penggunaan Cream Pemutih Wajah}

Icon Perempuan cantik juga sering menjadi inspirasi buat orang-orang disekitarnya, baik karena gaya busana mereka, gaya rambut mereka, ataupun perilaku mereka yang baik dan memang pantas diteladani. Iklan merupakan salah satu alat bauran promosi yang digunakan sebagai alat pengantar pesan untuk membentuk sikap konsumen Pengiklanan di media hingga kini masih dianggap cara paling efektif dalam mempromosikan produk, Periklanan merupakan salah satu bentuk promosi yang paling dikenal, karena daya jangkaunya yang luas. Iklan yang disenangi konsumen terlihat menciptakan sikap merek yang positif dan keinginan untuk membeli yang lebih ketimbang iklan yang tidak mereka sukai. (Peter\&Olson, 2000). Hasil penelitian dari 76 responden menunjukkan bahwa dari 46 orang mahasiswa katagori baik terdapat 27 orang (58,7\%) mahasiswa menggunakan cream pemutih wajah karna pengaruh dari media dan 19 orang (41,3\%) mahasiswa tidak menggunakan cream pemutih wajah. Dari 30 orang mahasiswa yang katagori kurang terdapat 26 orang (86,7\%) mahasiswa menggunakan cream pemutih wajah karena pengaruh media, ternyata hasil penelitian ini sesuai dengan teori yang menyatakan, Periklanan merupakan salah satu bentuk promosi yang paling dikenal, karena daya jangkaunya yang luas. Iklan yang disenangi konsumen terlihat menciptakan sikap merek yang positif dan keinginan untuk membeli. (Peter\&Olson, 2000).

Dari hasil analisis multivariat menunjukkan ( $P$ value $=0,004<0,05)$. Dengan nilai $\mathrm{B}=2,069$ bahwa ada pengaruh media massa terhadap penggunaan cream pemutih wajah pada Mahasiswa Jurusan Analis Kesehatan Poltekkes Kemenkes RI Medan.

Hasil penelitian tersebut menunjukkan bahwa ada pengaruh yang signifikan antara media iklan elektronik (televisi, radio, video film) dan media iklan cetak (koran, majalah, tabloid, brosur). Dari jawaban mahasiswa pada kuesioner tentang media massa ini, menggambarkan bahwa apa yang diinginkan dan cara pandang mahasiswa telah dirubah sesuai dengan keinginan produsen.

Kata Cantik telah dibentuk oleh media di dalam benak mahasiswa secara tidak sadar. Baik melalui iklan maupun tayangan-tayangan sinetron yang ada. Melalui ragam media, citra perempuan ditampilkan dengan berbagai daya tarik feminitasnya dan kelembutannya. Kalaupun ditampilkan maskulin, seperti agresif dan kasar serta berpakaian layaknya laki-laki, hal itu akan dianggap sebagai penyimpangan belaka.

Pemasang iklan harus sangat hati-hati dalam melakukan pemilihan endorser. (Belch dan Belch, 2001 ) Sebagian besar endorser (pemeran) yang dipakai dalam iklan adalah perempuan perempuan dengan tubuh yang langsing dan tinggi, berkulit putih, hidung mancung, paras yang manis, dan berambut panjang lurus. Stereotype ini telah terbentuk dan menjadi pemisah untuk perempuan "cantik" dan perempuan "tidak cantik". Begitu pula dengan sinetron-sinetron kita, pemeran utama sebagian besar selalu “cantik”. 


\section{KESIMPULAN}

1. Gaya hidup mahasiswa Jurusan Analis Poltekkes Kemenkes RI Medan pada umumnya banyak gaya hidup menggunakan cream pemutih yang dipengaruhi oleh 3 (tiga) variabel yaitu pengetahuan, teman dan media. Ternyata satu variabel sikap tidak memengaruhi dari gaya hidup mahasiswa.

2. Pengetahuan mahasiswa Jurusan Analis Poltekkes Kemenkes RI Medan berpengaruh terhadap gaya hidup penggunaan cream pemutih $(P=0,015)$.

3. Teman mahasiswa Jurusan Analis Poltekkes Kemenkes RI Medan berpengaruh terhadap gaya hidup penggunaan cream pemutih $(P=0,021)$.

4. Variabel yang paling berpengaruh terhadap gaya hidup penggunaan cream pemutih adalah media dengan nilai koefisien $\mathrm{B}=6,731$ atau $(P=0,009)$.

5. Variabel yang tidak memengaruhi terhadap gaya hidup penggunaan cream pemutih adalah sikap $(P=$ 0,275).

\section{SARAN}

Sesuai dengan kesimpulan yang diperoleh pada penelitian ini, dapat disampaikan beberapa saran sebagai berikut :

1. Pengetahuan dan wawasan tentang penggunaan cream pemutih wajah sangatlah mendukung dalam memilih produk yang akan kita gunakan, jangan hanya ingin tampil cantik hingga menggunakan sembarang produk yang dapat berakibat fatal

2. Tidak semua media yang kita dengar dan baca adalah benar, pilihlah media-media yang menyajikan iklan yang benar-benar kredible dan layak dipercaya.

3. Pergunakanlah cream pemutih wajah yang telah di analisa dan diuji oleh BPOM, untuk merk-merk tertentu yang dilarang dapat diketahui pada mediamedia atau yang dikeluarkan oleh BPOM.

\section{DAFTAR PUSTAKA}

Arikunto, 2002. Prosedur Penelitian, Jakarta : Rineka Cipta.

Badan POM RI. 2008. Bahan Berbahaya Dalam Kosmetik. In: Kosmetik Pemutih (Whitening), Naturakos, Vol.II1 No.8. Edisi Agustus 2008.Jakarta.

Bovee CL dan WF Arens, 1986, Comtemporary Advertising, Blionis: lnvin Homewood.

Chaney, David. 2003. Lifestyles : "Sebuah Pengantar Komprehensif” diterjemahkan oleh Nuraeni, Percetakan Jalasutra : Jakarta

Cyberwomen Healt. Ingin Kulit Wajah Putih, Haruskah Menggunakan Pemuth. http://cyberwomen.cbn.net.id/detail.asp? Kategori=helat\&news no: 677 (28 Oktober 2008)

Deviana, Nina. 2009. Pengetahuan, Sikap Dan Tindakan Mahasiswa Mengenai Kosmetik Mengandung Merkuri (Hg) di Akademi Kebidanan Hafsyah Medan Tahun 2009. Skripsi, FKM USU, Medan
Engel, J.F., R.D.Blackwell and Paul W. Miniard.1990. Consumer Behaviour. Six Edition.USA: The Drydeen Press.

Engel, James F, dkk. 1992. Perilaku Konsumen .Edisi Keenam. Jilid 1. Terjemahan oleh F.X.Budiyanto. 1994. Jakarta: Binarupa Aksara

Fina, Daulay, Y.G., 2006. Analisa Kadar Logam Merkuri (Hg) pada Beberapa Produk Kosmetik Krim Pemutih Produksi China yang Beredar di Pasar Ramai Kota Medan Tahun 2006. Skripsi, FKM USU, Medan

George, Belch E \& Michael A Belch. 2001. Advertising And Promotion : An Integrated Marketing Communications Perspective. 12th edition.

Hurlock, E. 1997. Psikologi Perkembangan Suatu Pendekatan Sepanjang Masa.

Alih Bahasa : Jakarta: Penerbit Erlangga.

Irawan, Handi. 2009. 10 karakteristik gaya hidupkonsumen Indonesia (online).(www.handiirawan.com, diakses 6November 2009

Kasali, Rhenald. 1998. Membidik Pasar Indonesia:Segmentasi, Targeting, dan Positioning .Jakarta: PT. Gramedia Pustaka Utama

Kotler, P. \& Amstrong. 2001. Prinsip-prinsip Pemasaran jilid I. Jakarta: Penerbit Erlangga.

Kusantati, Herni. 2008. Tata Kecantikan Kulit untuk SMK Jilid I. Jakarta :Direktorat Pembinaan Sekolah Menengah Kejuruan. Available from:http: //www.cosmetology.co.id/files/cdk/files/19152/pdf/ Tata Kecantikan Kulit Untuk SMK [ Accessed : 24 Maret 2010].Media Konsumen, 2006

Macmillan.Mowen, John. C dan Minor, Michael. 2001. Perilaku Konsumen. Edisi Kelima. Jilid 1.Terjemahan oleh Lina Salim. 2002. Jakarta:PT Penerbit Erlangga

McGraw HillHamel, Gary \& C.K. Prahalad. 1994. Competing for The Future. USA : Harvard Business School Press.

Monks, F.J. Knoers, A.M.P. Haditono, S.R. 2004. Psikologi Perkembangan.Yogyakarta: Gadjah Mada University Press.

Nandityasari, Ika. 2009. Hubungan Antara Ketertarikan Iklan Pond's di Televisi Dengan Keputusan Membeli Produk Pond's Pada Mahasiswa. Skripsi. Surakarta : Fakultas Psikologi Universitas Muhammadiyah Surakarta.

Notoatmodjo, Soekidjo, 2007. Promosi Kesehatan dan Ilmu Perilaku. Rineka Cipta:Jakarta Jakarta: Rineka Cipta

Peter, J Jaul \& Jerry C Olson. 1996/1999. Consumer Behaviour. 5th Edition ; Alih Bahasa : Perilaku Konsumen dan Strategi Pemasaran, edisi ke-4. Terjemahan: Damos Sihombing \& Peter Remy Yossi Pasla. Jakarta : Erlangga

Poetz, Maz, 2008. Kosmetik Mengandung Bahan Berbahaya dan Zat Warna yang Dilarang. http://roemahku.wordpress.com. Diakses 28 Juli 
2011

Poeradisastra, T. 2005. Menyibak Perilaku Konsumen Indonesia. Majalah Swasembada No. 06/XXI/1730 Maret 2005

Prabasmoro, Aquarini Priyatna. 2004. Putih, Feminitas dan Seksualitas Perempuan dalam Iklan Kita. Jakarta : Yayasan Jurnal Perempuan (Edisi : Remaja Melek Media)

Purnamawati, Sri Suriani. 2009. Perilaku Pekerja Perempuan Penyapu Jalan Terhadap Kosmetik Pemutih di Kota Medan Tahun 2009. Tesis. Medan : Program Studi Magister Ilmu Kesehatan Masyarakat Fakultas Kesehatan Masyarakat Universitas Sumatera Utara Medan.

Purwanto, Andi. 2009. Analisis Kesesuaian Iklan Produk Kosmetik Dengan Kep.Men.Kes Ri No: 386/Men.Kes/Sk/Iv/1994 Pada Lima Media Cetak Yang Beredar Di Kota Surakarta Periode Bulan Februari-April 2009. Sripsi. Surakarta: Fakultas Farmasi Universitas Muhammadiyah Surakarta

Sachari, Agus. 2007. Budaya Visual Indonesia .Jakarta: Erlangga.

Sarwono, Solita. 2004. Sosiologi Kesehatan: Beberapa Konsep Beserta Aplikasinya. Gadja Mada University Press : Yogyakarta.
Singarimbun, M., 1989. Metode Penelitian Survey, Jakarta : LP3ES

Solomon, Michael. 1994 Consumer Behaviour Second Edition. USA: Allyn and Baccon

Sutisna. 2002. Perilaku Konsumen danKomunikasi Pemasaran. Bandung: Rosda http://sehatnews.com/berita/7889-Hati-hatiMenggunakan-Pemutih-Wajah. html, diakses tanggal 20 September 2011.

Tranggono, Iswari, Retno; Latifah, Fatimah, 2007. Buku Pegangan Ilmu Pengetahuan Kosmetik. Gramedia Pustaka Utama, Jakarta

Yani, Mona Siska. 2008. Hubungan Faktor-faktor Risiko Terhadap Kejadian Melasma pada Pekerja Wanita Penyapu Jalan di Kota Medan Tahun 2008.

Zaini, Hisyam, dkk. 2002. Desain Pembelajaran di Perguruan Tinggi. Yogyakarta: Center for Teaching and Staf Development, IAIN Sunan Kalijaga.

Zebua, A.S, Nurdjayadi, R.D. 2001. Hubungan antara Konformitas dan Konsep Diri dengan Perilaku Konsumtif pada Remaja Putri. Jurnal Ilmiah Psikologi Terapan: Phronesis. Vol. 3, No.6. 